\title{
Effect of Different Sowing Dates and Irrigation Scheduling on Productivity of Moth Bean
}

\author{
Manraj Yadav* and J.J. Patel \\ Anand Agricultural University, Anand, Gujarat-302018, India \\ *Corresponding author
}

\begin{tabular}{|l|}
\hline Ke y w o r d s \\
Date of sowing, \\
Irrigation \\
scheduling, Crop \\
productivity and \\
Moth bean
\end{tabular}

A B S T R A C T
A field experiment was conducted during summer season of the year 2010 at Anand Agricultural University, Anand, Gujarat to study the influence of date of sowing and irrigation scheduling on productivity of summer moth bean. The results indicated that treatment $\mathrm{D}_{2}$ sowing at $\left(30^{\text {th }}\right.$ January) recorded the highest plant height $(10.00 \mathrm{~cm}, 19.50$ $\mathrm{cm}$ and $27.05 \mathrm{~cm}$ at 30,60 DAS and at harvest, respectively. While the lowest plant height $(6.25 \mathrm{~cm}, 16.33$ and $21.13 \mathrm{~cm}$ at $30,60 \mathrm{DAS}$ and at harvest, respectively) was observed under $20^{\text {th }}$ January sowing $\left(\mathrm{D}_{1}\right)$. Date of sowing had significant effect on seed yield of moth bean. Significantly the highest seed $(460 \mathrm{~kg} / \mathrm{ha})$ was recorded under treatment $\mathrm{D}_{2}$ (sowing at $30^{\text {th }}$ January). Whereas, significantly lower seed $(368 \mathrm{~kg} / \mathrm{ha})$ was under treatment $D_{1}$ (sowing at $20^{\text {th }}$ January). Treatment $D_{2}$ (sowing at $30^{\text {th }}$ January) increase seed yield to the tune of $18.26 \%, 19.78 \%$ and $20 \%$ over the treatments $\mathrm{D}_{3}$ (sowing at $9^{\text {th }}$ February), $\mathrm{D}_{4}$ (sowing at $19^{\text {th }}$ February) and $\mathrm{D}_{1}$ (sowing at $20^{\text {th }}$ January), respectively. Among the different levels of irrigation scheduling, application of irrigation at $0.7 \mathrm{IW}$ :CPE ratio $\left(I_{2}\right)$ recorded significantly higher average plant height $(11.37,19.76,27.95 \mathrm{~cm})$ at 30 and 60 DAS and at harvest, average length of pod $(3.78 \mathrm{~cm})$, significantly the lowest seed $(319 \mathrm{~kg} / \mathrm{ha})$ was observed under treatment $\mathrm{I}_{0}$ (control, irrigation at critical growth stages). Result revealed that treatment combination of $\left(\mathrm{D}_{2} \mathrm{I}_{2}\right), 30^{\text {th }}$ January date of sowing of moth bean with irrigation scheduling based on IW:CPE ratio 0.7 ( $8+1$ irrigation) recorded significantly the highest seed yield $(651 \mathrm{~kg} / \mathrm{ha})$. For securing higher seed yield and net realization from summer moth bean it is advisable that crop should be sown at $30^{\text {th }}$ January with nine irrigations, each of $50 \mathrm{~mm}$ depth scheduled at an IW:CPE ratio of 0.7 .

\section{Introduction}

Moth bean [Vigna acontifolia (Jacq.) Marechal] originated in the semi-arid regions of India, most probably in the State of Rajasthan (Fageria, 1992). It is cultivated in the states of Rajasthan, Haryana, Utter Pradesh, Punjab, Maharashtra, and Gujarat.
The most common sowing practice was through broadcast. In Punjab, it was cultivated with black and green grams as a mixed crop, more often in the unfertile soils. It is a groundhugging plant and only about a one foot high. The crop is generally grown in the north Western deserts regions of India and Pakistan, especially in area where moong bean greatly 
suffers from drought. Production of moth bean varies in the India, and all production is consumed within the country. The lower productivity of this crop is attributed to several factors such as growing under moisture stress conditions, marginal lands with very low inputs and without pest and disease management, non availability of high yielding varieties and late sowing. Moreover, the yield of local cultivars of moth been is much less as compared to other pulse crops. Hence, there is need to enhance the production potential of this crop through use of organic manures, biofertilizers. Chemical fertilizers play an important role to meet the nutrient requirement of the crop but continuous use of these on lands will have deleterious effects on physical chemical and biological properties of soil, which in turn reflects on yield (Sarkar et al., 1992).

Date of Sowing has been recognized as the most important non-monetary input affecting yield of summer moth bean as late sowing coincides with high temperature during the initial crop growth stage and pre- monsoon shower at reproductive stage. On the other hand, early sown crop faces moderate temperature during initial growth stage, particularly in middle Gujarat region, which adversely affect the crop growth and finally the yield. Late sowing does not provide enough time to prepare land for kharif crop, which delays kharif sowing. Therefore, it is imperative to determine the optimum time of sowing of moth bean crop for obtaining higher economic yield. Water is well known essential constituent of living organism for their growth and development. Both excess or deficit use of water, reduces the crop yield drastically. Water stress during the active crop growth phase results into cessation of growth as it influences the photosynthesis and other physiochemical processes and or death, by desiccation. The excess water leads to the problems of raising water table, soil salinity.
Hence, water management studies have become an important aspect of research for irrigated crops. Irrigation is mainly given to crop for achieving maximum yield with batter quality of produce. The ideal scheduling of irrigation depends upon the soil, climate and plant characteristics. Keeping all these factors in view, the present research work entitled "Influence of date of sowing and irrigation scheduling (IW:CPE ratios) on growth, yield attributes and yield of summer moth bean under middle Gujarat conditions.

\section{Materials and Methods}

The present experiment was conducted at Agronomy Farm of Anand Agricultural University, Anand, (Gujarat) during summer season of the year 2010. The climate of this region is semi-arid and sub-tropical with an average rainfall of $870 \mathrm{~mm}$ received entirely from the south west monsoon current. Winter is severe and sets in the month of November and continued till the end of January. Summer is hot and dry, covers the month of April-May.

The mean minimum temperature ranged from $12.2^{\circ} \mathrm{C}$ to $23.7^{\circ} \mathrm{C}$ and mean maximum temperature ranged from $30.3^{\circ} \mathrm{C}$ to $41.7^{\circ} \mathrm{C}$ during the crop season of the year 2010. The soil is representative of the soils of the region and is particularly known as 'Goralu soil' which alluvial in origin and belongs to the Entisols. It responds well to manuring and is suitable to variety of crop of tropical region. The soil is very deep and moisture retentive. The soil was low in nitrogen, medium in available phosphorus and high in available potash.

The soil is free from any kind of salinity and sodicity. The detail of experimental techniques employed for the investigation was stripe plot consisted four date of sowing i.e. $\mathrm{D}_{1}=20^{\text {th }}$ January, $\mathrm{D}_{2}=30^{\text {th }}$ January, $\mathrm{D}_{3}=9^{\text {th }}$ February and $\mathrm{D}_{4}=19^{\text {th }}$ February as first stripe and four 
irrigation scheduling levels i.e. $\mathrm{I}_{0}$ - critical growth stages @ Branching, at flowering, at pod formation, at grain formation. (Control), $\mathrm{I}_{1}-0.5 \mathrm{IW}$ : CPE ratio, $\mathrm{I}_{2}-0.7 \mathrm{IW}$ : CPE ratio and $\mathrm{I}_{3}-0.9 \mathrm{IW}$ : CPE ratio.

The experimental field was thoroughly prepared by tractor cultivator followed by harrowing and at last planking for leveled the soil. The seeds of Moth bean were used for sowing. As per the date of sowing treatments, first, second, third, and four sowing was done manually on $20^{\text {th }}$ January, $30^{\text {th }}$ January, $9^{\text {th }}$ February and $19^{\text {th }}$ February 2010, respectively. First treated seed with Rhizobium culture 'pv movable'@400gm/20kg seeds and then dry sowing was done at $60 \mathrm{~cm}$ row to row and 10 $\mathrm{cm}$ plant to plant distance.

The crop was fertilized with $20 \mathrm{~kg} \mathrm{~N}$ and 40 $\mathrm{kg} \mathrm{P}_{2} \mathrm{O}_{5}$ per hectare from DAP and urea as basal application i.e. before sowing in opened furrow as common application. Thinning, weeding and plant protection measures were taken as and when required. Plant protection measures were adopted as and when required. Pods were harvested manually when they turned brown to dark brown. The pods from border lines were harvested first and kept separately.

Then, the pods from net plot were manually picked and allowed to sun dry for four days in cotton bags. The seed weight of each net plot was done by pan balance and recorded for each net plot separately. Five randomly selected and tagged plants from each plot were used for recording observation on yield attributes. The data generated on yield, quality and various characterized were subjected to statistical analysis using "Analysis of variance technique". The value of table ' $\mathrm{F}$ at $5 \%$ level of significance, where the treatment differences were found significant the value of $\mathrm{CD}$ and C.V. \%were also worked out to compare the treatment mean (Snedecor and Cochran, 1967).

\section{Results and Discussion}

\section{Effect of date of sowing and irrigation scheduling (IW:CPE ratios) on plant height}

The effect of date of sowing on plant height at 30 and 60 DAS and at harvest was significant (Table 1). Sowing of the crop at $30^{\text {th }}$ January $\left(D_{2}\right)$ recorded the highest plant height $(10.00$ $\mathrm{cm}, 19.50 \mathrm{~cm}$ and $27.05 \mathrm{~cm}$ at 30,60 DAS and at harvest, respectively. While the lowest plant height $(6.25 \mathrm{~cm}, 16.33 \mathrm{~cm}$ and $21.13 \mathrm{~cm}$ at 30 , 60 DAS and at harvest, respectively) was observed under $20^{\text {th }}$ January sowing $\left(D_{1}\right)$. Treatments $\mathrm{D}_{3}$ sowing date $\left(9^{\text {th }}\right.$ Feb.) and $\mathrm{D}_{4}$ $\left(19^{\text {th }}\right.$ Feb.) were remained at par with each other's at 30 DAS.

Similar trend was also observed at 60 DAS and at harvest. This might be due to the fact that optimum climate conditions prevailed during the vegetative growth period under $30^{\text {th }}$ January $\left(D_{2}\right)$ promoted the cell division and there by stem elongation that virtually increased plant growth in terms of plant height. It is cleared from data (Table 1) that irrigation scheduling (IW:CPE ratios) was able to exert its significant effect on plant height at 30, 60 DAS and at harvest. Treatment $\mathrm{I}_{2}$ (0.7 IW:CPE ratio) recorded significantly the highest average plant height $(11.37,19.76,27.95 \mathrm{~cm})$, than rest of the irrigation levels. Treatments $\mathrm{I}_{3}$ (0.9 IW:CPE ratio), $\mathrm{I}_{1}$ (0.5 IW:CPE ratio) were remained at par with each other. While the lowest plant height were recorded under treatment $\mathrm{I}_{0}$ Control (Irrigation at critical growth stages). The increase in the plant height under treatment $\mathrm{I}_{2}$ (0.7 IW:CPE ratio) might be due to optimum supply of soil moisture surrounding root zone by favourably improving the nutrient uptake and translocation which ultimately linked with the plant growth and development in terms of plant height due to frequent irrigation (9) as compared to that of $\mathrm{I}_{0}$ control [Irrigation (4) at critical growth stages]. Optimum moisture 
supply promoted the cell division and cell expansion and there by stem elongation which virtually increased the plant growth in terms of plant height. These results are in accordance with those reported by Trivedi $e t$ al., (1994), Dabhi et al., (1998), Kavita and Wahab (2000) for green gram.

Effect of date of sowing and irrigation scheduling on seed yield

Date of sowing had significant effect on seed yield of moth bean (Table 2). Significantly the highest seed yield $(460 \mathrm{~kg} / \mathrm{ha})$ was recorded under treatment $\mathrm{D}_{2}$ (sowing at $30^{\text {th }}$ January). Whereas, significantly lower seed yield (368 $\mathrm{kg} / \mathrm{ha}$ ) was under treatment $\mathrm{D}_{1}$ (sowing at $20^{\text {th }}$ January), being at par with treatments $\mathrm{D}_{4}$ (sowing at $19^{\text {th }}$ February), $\mathrm{D}_{3}$ (sowing at $9^{\text {th }}$ February), respectively. Treatment $\mathrm{D}_{3}$ (sowing at $9^{\text {th }}$ February) and Treatment $\mathrm{D}_{4}$ (sowing at $19^{\text {th }}$ February) were remained at par with each other. Treatment $\mathrm{D}_{2}$ (sowing at $30^{\text {th }}$ January) recorded higher seed yield to the tune of $18.26 \%, 19.78 \%$ and $20 \%$ over the treatments $\mathrm{D}_{3}$ (sowing at $9^{\text {th }}$ February), $\mathrm{D}_{4}$ (sowing at $19^{\text {th }}$ February) and $\mathrm{D}_{1}$ (sowing at $20^{\text {th }}$ January), respectively. Significantly the highest seed yield (472 kg/ha) was observed under treatment $\mathrm{I}_{2}$ (0.7 IW:CPE ratio), whereas significantly the lowest seed yield $(319 \mathrm{~kg} / \mathrm{ha})$ was observed by treatment $\mathrm{I}_{0}$ (control, irrigation at critical growth stages). Treatment $\mathrm{I}_{1}$ (0.5 IW:CPE ratio) was remained at par with treatment $\mathrm{I}_{3}$ (0.9 IW:CPE ratio). Treatment $\mathrm{I}_{2}$ (0.7 IW:CPE ratio) recorded higher seed yield at the extant of $16.73 \%$, $17.58 \%$, and $32.41 \%$ over the treatments $\mathrm{I}_{1}$ (0.5 IW:CPE ratio), $\mathrm{I}_{3}$ (0.9 IW:CPE ratio) and $\mathrm{I}_{0}$ (control, irrigation at critical growth stages), respectively.

Table.1 Effect of date of sowing and irrigation scheduling on plant height

\begin{tabular}{|c|c|c|c|}
\hline \multirow[t]{2}{*}{ Treatment } & \multicolumn{3}{|c|}{ Plant height(cm) } \\
\hline & At 30 DAS & At 60 DAS & At harvest \\
\hline \multicolumn{4}{|c|}{ A Vertical strip (Date of sowing) } \\
\hline$D_{1}: 20^{\text {th }}$ January & 6.25 & 15.17 & 21.13 \\
\hline$D_{2}: 3^{\text {th }}$ January & 10.00 & 19.50 & 27.05 \\
\hline$D_{3:} 9^{\text {th }}$ February & 8.86 & 17.42 & 25.21 \\
\hline$D_{4}: 19^{\text {th }}$ February & 8.53 & 16.35 & 24.56 \\
\hline S.Em. \pm & 0.36 & 0.32 & 0.34 \\
\hline C.D. at 5\% & 1.14 & 1.04 & 1.10 \\
\hline \multicolumn{4}{|c|}{ B Horizontal strip (Irrigation IW:CPE ratios ) } \\
\hline $\mathbf{I}_{\mathbf{0}}$ :Control & 8.13 & 16.52 & 20.06 \\
\hline$I_{1:} 0.5$ IW:CPE ratio & 8.39 & 17.03 & 24.39 \\
\hline$I_{2}: 0.7$ IW:CPE ratio & 11.37 & 19.76 & 27.95 \\
\hline 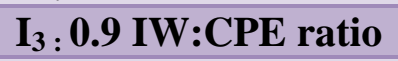 & 9.13 & 17.74 & 24.56 \\
\hline S.Em. \pm & 0.34 & 0.32 & 0.66 \\
\hline C.D. at $5 \%$ & 1.12 & 1.04 & 2.04 \\
\hline
\end{tabular}


Table.2 Effect of date of sowing and irrigation scheduling on seed yield

\begin{tabular}{|c|c|}
\hline Treatments & Seed yield $\left(\mathrm{Kg} \mathrm{ha}^{-1}\right)$ \\
\hline \multicolumn{2}{|c|}{ A Vertical strip (Date of sowing) (D) } \\
\hline$D_{1:} 2^{\text {th }}$ January & 368 \\
\hline$D_{2}: 3^{\text {th }}$ January & 460 \\
\hline$D_{3:} 9^{\text {th }}$ February & 376 \\
\hline$D_{4}: 19^{\text {th }}$ February & 369 \\
\hline S.Em. \pm & 8.00 \\
\hline C.D. at $5 \%$ & 25 \\
\hline \multicolumn{2}{|c|}{ B Horizontal strip (Irrigation IW:CPE ratios ) (I) } \\
\hline I0 : Control & 319 \\
\hline I1 : 0.5 IW:CPE ratio & 393 \\
\hline I2 : 0.7 IW:CPE ratio & 472 \\
\hline I3 : 0.9 IW:CPE ratio & 389 \\
\hline S.Em. \pm & 13 \\
\hline C.D. at 5\% & 41 \\
\hline
\end{tabular}

For securing higher seed yield and net realization from summer moth bean crop $\mathrm{Cv}$. RMO-225 raised on loamy sand soil of middle Gujarat, it is advisable that crop should be sown at 30th January with nine irrigations, each of $50 \mathrm{~mm}$ depth scheduled at an IW:CPE ratio of 0.7 . The common irrigation should be applied immediately after dry sowing; first irrigation at fourteen days after common irrigation and second at also fourteen days after first irrigation and remaining six irrigations should be applied at an interval of seven to ten days.

\section{References}

Dabhi, B. M.; Patel, J. C and Solanki, R. M. (1998). Response of summer greengram to irrigation methods and varying moisture regimes. Legume Research, 21(2): 96-100.
Fageria (1992). Asian Agri History 10 (3) 179-202

Kavita, R. and Wahab, K. (2000). Effect of irrigation and mulching practices on growth parameters and yield of greengram. Madras Agric. J., 88(4-6): 359-360.

Sarkar, R.K. (1992). Response of summer greengram to irrigation and phosphorus application. Ind. J. Agron., 37(1): 123-125.

Snedecor, G. W. and Cochram, W. G. (1967). "Statistical method". The IOWA State University Press, IOWA.

Trivedi, D.V.: Ahalawat, R.P.S.and Trivedi, S.J. (1994). Effect of varying irrigation schedules, depth of ploughing and mulches on growth and yield of summer green gram Ind J.Agron., 39(4): 667-669.

\section{How to cite this article:}

Manraj Yadav and Patel, J.J. 2019. Effect of Different Sowing Dates and Irrigation Scheduling on Productivity of Moth Bean. Int.J.Curr.Microbiol.App.Sci. 8(12): 738-742. doi: https://doi.org/10.20546/ijcmas.2019.812.097 